\title{
Illness and injury of travellers abroad: Finnish nationwide data from 2010 to 2012, with incidences in various regions of the world
}

H Siikamäki ${ }^{1,2}$, P Kivelä ${ }^{1}$, M Fotopoulos ${ }^{2}$, J Ollgren³, A Kantele (anu.kantele@hus.fi) ${ }^{1,4,5}$

1. Inflammation Center, Clinic for Infectious Diseases, University of Helsinki and Helsinki University Hospital, Helsinki, Finland

2. SOS International, Frederiksberg, Denmark

3. National Institute for Health and Welfare, Helsinki, Finland

4. Department of Medicine, University of Helsinki, Helsinki, Finland

5. Unit of Infectious Diseases, Department of Medicine Solna, Karolinska Institutet, Stockholm, Sweden

The number of international tourist arrivals reached 1,000 million in 2012. Assessment of travellers' health problems has relied on proportionate morbidity data. Given the lack of data on number of visitors to each region, incidences have been impossible to calculate. This study, largest yet reporting travellers' health problems, is the first to present incidence of illness and injury. Data on Finnish travellers with health problems abroad during 2010 to 2012 were retrieved from the database of an assistance organisation, SOS International, covering $95 \%$ of those requiring aid abroad. The numbers were compared with those of Finnish travellers in the database of the Official Statistics of Finland. The SOS International database included 50,710 cases: infections constituted the most common health problem $(60 \%)$, followed by injuries ( $14 \%$ ), diseases of skin ( $5 \%)$, musculoskeletal system and connective tissue ( $5 \%$ ), digestive tract (3\%), and vascular system (2\%). Gastroenteritis (23\%) and respiratory infections ( $21 \%$ ) proved the most frequent diagnoses. Overall incidence of illness or injury was high in Africa (97.9/100,000 travel days; 95\% Bayesian credible interval (BCI): 53.1-145.5), southern Europe plus the eastern Mediterranean (92.3; 95\% BCI: $75.4^{-}$ 110.1) and Asia (65.0; $95 \% \mathrm{BCl}$ : 41.5-87.9). The data show significant differences between geographical regions, indicating the main risks and thus providing destination-specific tools for travellers' healthcare.

\section{Introduction}

The annual number of international tourist arrivals globally exceeded 1,000 million in 2012 and is expected to reach 1,800 million by 2030 [1]. Of those travelling from developed to developing countries, over half have been reported to fall ill while abroad and $8 \%$ to require medical attention [2]. The growing volume of travel means an increased burden on healthcare both in host countries and at home.

Assessment of travellers' health problems has largely been based on calculations of proportionate morbidity of returning travellers as reported by specialised centres for travel and tropical medicine [3-6]. Data on illness or injury while abroad have been collected chiefly after travel from questionnaires, telephone surveys [2,7-14] and insurance claims $[15,16]$, data recorded during actual travel are scarce. While a few studies have reviewed emergency-assistance services of individual insurance companies [17-19], comprehensive information on travellers' health problems abroad is non-existent. Furthermore, epidemiological data allowing calculation of the incidence of the whole spectrum of health problems in relation to number of travellers seem to be completely lacking [20].

The study presented here draws on the particular conditions found in Finland, a country with a population of 5.5 million [21]. Approximately $95 \%$ of those requiring help of an assistance organisation because of health problems while abroad are recorded in the database of SOS International (SOS), serving several insurance companies. In addition, Finland is among the few countries monitoring their annual number of travellers to various destinations. According to the Official Statistics of Finland (OSF) database [22], in 2012 Finns made 7.7 million visits abroad in which they stayed for at least overnight. Combining these two large datasets enabled determination not only of travellers' proportionate morbidity but, more importantly, also incidence of health problems. 
Overview of course of Finnish travellers' health problems abroad and study population, 2010-12 $(\mathrm{n}=50,710)$

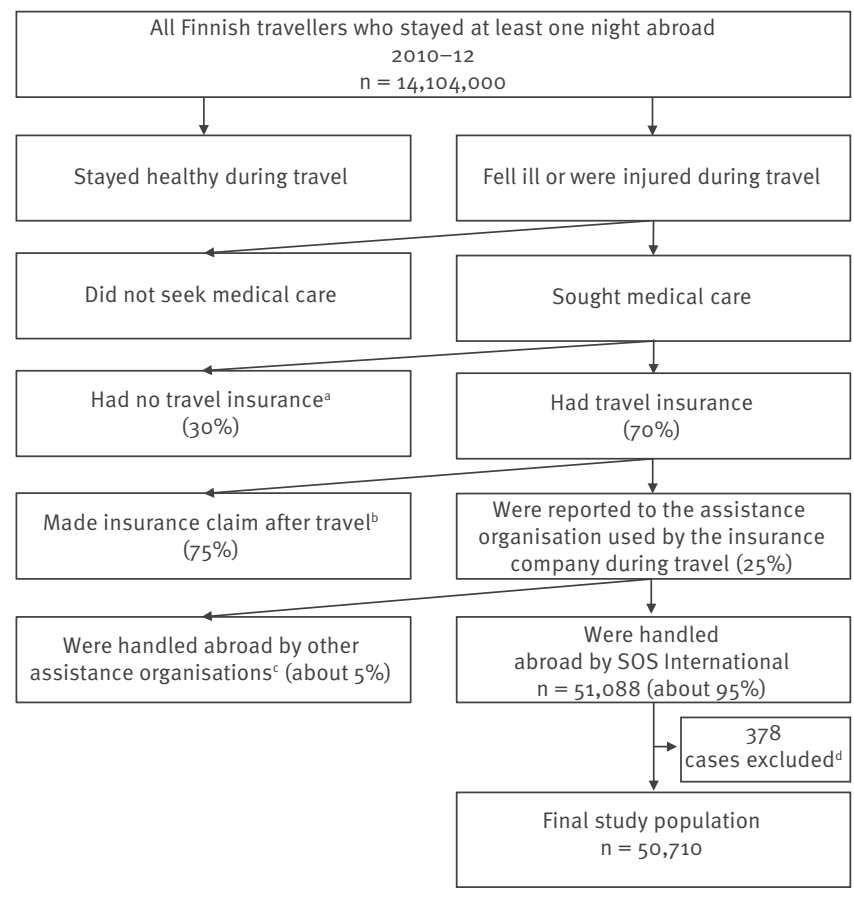

Source: Federation of Finnish Financial Services.

Vakuutustutkimus 2012. [Insurance survey 2012] [30].

Source: Claims specialist Ilkka Valanne, Eurooppalainen, personal communication, 2 October 2013.

Source: Medical director Ari Kinnunen, EMA Finland, and

Medical Director Pauli Haapsaari, MedFlight Finland, personal

communication, 3 September 2013.

d Excluded because of incomplete information.

\section{Methods}

\section{Assistance organisation data}

SOS, serving Nordic and Baltic insurance companies, provides travellers with 24-hour emergency assistance abroad: advice, medical evaluation, referral to treatment, cost coverage and arrangement of transportation if indicated for medical reasons. SOS covers approximately $95 \%$ of all Finnish cases $(77 \%$ of inpatients, $99.8 \%$ of outpatients) handled abroad by assistance organisations (Figure 1); records for 2010 to 2012 were included in this analysis.

All SOS data are processed in a computerised database. Coordinating doctors are assigned to approximately $86 \%$ of inpatient and $1 \%$ of outpatient cases. They stay in contact with the patient and clinician abroad, examine medical reports, evaluate treatment and give orders for repatriation. Non-medical assistance coordinators see to the uncomplicated inpatient and outpatient cases, recording diagnoses provided by clinicians abroad.

Information available for our study comprised age, sex, time and country of illness or injury, inpatient or outpatient status, main diagnosis, repatriation and death.
Research clearance was received from SOS.

\section{Definitions}

A case was defined as a Finnish traveller abroad with one episode of illness or injury, handled by SOS during 2010 to 2012. A person with several separate episodes was counted more than once. Classification as inpatient was based on information from the hospital abroad. Any case not recorded as an inpatient but who had at least one outpatient visit was classified as an outpatient case. Deceased travellers who had not been registered as inpatients were entered as outpatient cases, with their diagnoses being unavailable.

Repatriations were grouped by return: as planned, air ambulance, or other rearranged transport. The data collection procedure included as inpatients those outpatient cases whose flights had to be rescheduled.

To describe the study population and proportionate morbidity of all cases, countries were classified into the following geographical regions: southern Europe (the Balkan states, Cyprus, Greece, Italy, Malta, Portugal including Madeira, Spain including the Canary Islands); rest of Europe; the eastern Mediterranean (Israel, Turkey); North Africa; sub-Saharan Africa; western Asia; south-central Asia (from Pakistan to Bangladesh); south-east Asia; north-east Asia; Central and South America and the Caribbean; North America; Australia, New Zealand and Oceania. For incidence calculations, the geographical classification was modified to be compatible with the OSF classification [22].

Travel seasons were categorised by first date of symptom onset or injury, being divided into winter (October to March) and summer (April to September).

\section{Diagnoses}

Coordinating doctors encoded diagnoses applying the International Statistical Classification of Diseases and Related Health Problems 10th revision (ICD-10) [23]. Assistance coordinators recorded them as open text. For our study, a single coordinating doctor, one of the researchers (H.S.), encoded these diagnoses by applying ICD-10. The diagnostic categories were those of ICD-10, excluding infections, which we separated from the organ-specific classification into a category of their own.

\section{Data on Finnish travellers}

Obtained from the database of OSF, the pre-existing traveller data contained annual numbers and median duration of at-least-overnight leisure and business visits abroad, and travellers' age groups by region and country. Country-specific data were available for those receiving more than 50,000 visitors per year. OSF data had initially been collected by monthly sample-based computer-assisted telephone interviews with Finnish residents aged 15 to 74 years; the upper age limit was extended to 84 years in 2012. Drawn systematically 
TABLE 1

Characteristics of outpatient and inpatient cases ${ }^{\mathrm{a}}$ among travellers abroad and risk factors for hospitalisation, 2010-12 $(\mathrm{n}=50,710)$

\begin{tabular}{|c|c|c|c|c|c|c|}
\hline \multirow[b]{2}{*}{ Characteristic } & \multirow[b]{2}{*}{ Total } & \multirow{2}{*}{$\begin{array}{l}\text { Outpatient } \\
\text { cases }\end{array}$} & \multirow[b]{2}{*}{ Inpatient cases } & \multirow[b]{2}{*}{ P value } & \multicolumn{2}{|c|}{ Risk factors for hospitalisation } \\
\hline & & & & & $\begin{array}{l}\text { Univariable } \\
\text { OR }(95 \% \text { CI) }\end{array}$ & $\begin{array}{l}\text { Multivariable } \\
\text { OR }(95 \% \mathrm{CI})^{\mathrm{b}}\end{array}$ \\
\hline Number of cases, $\mathrm{n}$ & 50,710 & 42,371 & 8,339 & NA & NA & NA \\
\hline \multicolumn{7}{|l|}{ Sex, n (\%) } \\
\hline Male & $22,849(45.1)$ & $18,500(43.7)$ & $4,349(52.2)$ & $<0.001$ & $1.41(1.34-1.47)$ & $1.33(1.26-1.40)$ \\
\hline Female & $27,861(54.9)$ & $23,871(56.3)$ & $3,990(47.8)$ & $<0.001$ & 1.00 & 1.00 \\
\hline \multicolumn{7}{|l|}{ Age in years } \\
\hline Median age (IQR) & $45(21-61)$ & $44(20-61)$ & $48(27-64)$ & $<0.001$ & NA & NA \\
\hline \multicolumn{7}{|l|}{ Age groups, n (\%) } \\
\hline $0-14$ & $9,752(19.2)$ & $8,687(20.5)$ & $1,065(12.8)$ & $<0.001$ & $0.59(0.56-0.62)$ & $0.61(0.57-0.65)$ \\
\hline $15-29$ & $6,872(13.6)$ & $5,528(13.0)$ & $1,344(16.1)$ & $<0.001$ & $1.17(1.10-1.23)$ & $1.08(1.02-1.15)$ \\
\hline $30-44$ & $8,373(16.5)$ & $6,978(16.5)$ & $1,395(16.7)$ & 0.132 & $0.96(0.91-1.01)$ & $0.85(0.81-0.91)$ \\
\hline $45-59$ & $11,135(22.0)$ & $9,373(22.1)$ & $1,762(21.1)$ & $<0.001$ & $0.90(0.86-0.96)$ & $0.86(0.82-0.91)$ \\
\hline $60-74$ & $12,576(24.8)$ & $10,301(24.3)$ & $2,275(27.3)$ & $<0.001$ & $1.06(1.01-1.11)$ & $1.13(1.07-1.19)$ \\
\hline $75-100$ & $2,002(3.9)$ & $1,504(3.5)$ & $498(6.0)$ & $<0.001$ & $1.60(1.46-1.73)$ & $1.83(1.66-2.02)$ \\
\hline \multicolumn{7}{|l|}{ Region, n (\%) } \\
\hline $\begin{array}{l}\text { Europe and eastern } \\
\text { Mediterranean }\end{array}$ & $36,699(72.4)$ & $31,208(73.7)$ & $5,491(65.8)$ & NA & NA & NA \\
\hline Southern Europe ${ }^{c}$ & $27,202(53.6)$ & $24,278(57.3)$ & $2,924(35.1)$ & $<0.001$ & $0.17(0.15-0.19)$ & $0.16(0.14-0.19)$ \\
\hline Eastern Mediterranean ${ }^{d}$ & $7,539(14.9)$ & $5,684(13.4)$ & $1,855(22.2)$ & $<0.001$ & $0.46(0.40-0.52)$ & $0.55(0.48-0.64)$ \\
\hline Rest of Europe ${ }^{e}$ & $1,958(3.9)$ & $1,246(2.9)$ & $712(8.5)$ & 0.004 & $0.80(0.68-0.93)$ & $0.73(0.62-0.85)$ \\
\hline Africa & $3,262(6.4)$ & $2,739(6.5)$ & $523(6.3)$ & NA & NA & NA \\
\hline North Africa & $3,121(6.2)$ & $2,721(6.4)$ & $400(4.8)$ & $<0.001$ & $0.21(0.18-0.24)$ & $0.28(0.24-0.33)$ \\
\hline Sub-Saharan Africa $^{f}$ & $141(0.3)$ & $18(0.04)$ & $123(1.5)$ & $<0.001$ & $9.54(5.96-15.25)$ & $10.61(6.54-17.22)$ \\
\hline Asia & $10,119(20.0)$ & 8,019 (18.9) & $2,100(25.2)$ & NA & NA & NA \\
\hline South-east Asia & $9,514(18.8)$ & $7,746(18.3)$ & $1,768(21.2)$ & $<0.001$ & $0.32(0.28-0.37)$ & $0.37(0.32-0.43)$ \\
\hline South-central Asiag & $361(0.7)$ & $167(0.4)$ & $194(2.3)$ & $<0.001$ & $1.60(1.29-2.04)$ & $1.77(1.40-2.25)$ \\
\hline North-east Asia & $194(0.4)$ & $90(0.2)$ & $104(1.2)$ & 0.001 & $1.60(1.21-2.15)$ & $1.49(1.10-2.03)$ \\
\hline Western Asia & $50(0.1)$ & $16(0.04)$ & $34(0.4)$ & $<0.001$ & $2.97(1.70-5.18)$ & $2.96(1.63-5.37)$ \\
\hline The Americas & $609(1.2)$ & $402(0.9)$ & $207(2.5)$ & NA & NA & NA \\
\hline $\begin{array}{l}\text { Central and South America and } \\
\text { the Caribbean }\end{array}$ & $366(0.7)$ & $214(0.5)$ & $152(1.8)$ & 0.940 & $0.99(0.79-1.25)$ & $1.13(0.89-1.43)$ \\
\hline North America & $243(0.5)$ & $188(0.4)$ & $55(0.7)$ & $<0.001$ & $0.41(0.30-0.55)$ & $0.31(0.22-0.42)$ \\
\hline $\begin{array}{l}\text { Australia, New Zealand and } \\
\text { Oceania }\end{array}$ & $21(0.04)$ & $3(0.007)$ & $18(0.2)$ & $<0.001$ & $8.37(2.72-25.74)$ & $5.17(1.64-16.27)$ \\
\hline \multicolumn{7}{|l|}{ Season, n (\%) } \\
\hline Winter $^{\mathrm{h}}$ & $30,032(59.2)$ & $25,054(59.1)$ & $4,978(59.7)$ & NA & 1.00 & NA \\
\hline Summeri & $20,678(40.8)$ & $17,317(40.9)$ & $3,361(40.3)$ & 0.337 & $0.98(0.93-1.03)$ & NA \\
\hline \multicolumn{7}{|l|}{ Diagnostic category, n (\%) } \\
\hline Infections & $30,386(59.9)$ & $26,324(62.1)$ & $4,062(48.7)$ & NA & 1.00 & 1.00 \\
\hline Injuries & $7,095(14.0)$ & $5,592(13.2)$ & $1,503(18.0)$ & $<0.001$ & $1.74(1.63-1.86)$ & $1.66(1.55-1.78)$ \\
\hline Skin diseases & $2,639(5.2)$ & $2,615(6.2)$ & $24(0.3)$ & $<0.001$ & $0.59(0.04-0.09)$ & $0.058(0.04-0.09)$ \\
\hline $\begin{array}{l}\text { Musculoskeletal and connective } \\
\text { tissue diseases }\end{array}$ & $2,621(5.2)$ & $2,475(5.8)$ & $146(1.8)$ & $<0.001$ & $0.38(0.32-0.45)$ & $0.38(0.32-0.46)$ \\
\hline Diseases of the digestive tract & $1,292(2.5)$ & $836(2.0)$ & $456(5.5)$ & $<0.001$ & $3.54(3.14-3.98)$ & $3.24(2.86-3.67)$ \\
\hline Vascular diseases & $1,081(2.1)$ & $369(0.9)$ & $712(8.5)$ & $<0.001$ & $12.50(10.98-14.24)$ & $12.40(10.8-14.2)$ \\
\hline Other & $5,596(11.0)$ & $4,160(9.8)$ & $1,436(17.2)$ & $<0.001$ & $2.40(2.09-2.40)$ & $2.30(2.15-2.48)$ \\
\hline
\end{tabular}

$\mathrm{Cl}$ : confidence interval; IQR: interquartile range; NA: not applicable; OR: odds ratio.

The values in bold indicate data for main geographical regions.

A case was defined as a Finnish traveller abroad with one episode of illness or injury, handled by SOS International during 2010 to 2012 . A

Deviation from average effect used as reference in variables region and age group.

Balkan states, Cyprus, Greece, Italy, Malta, Portugal including Madeira, Spain including Canary Islands.

Israel, Turkey.

European countries not included in southern Europe.

including South Africa.

from Pakistan to Bangladesh.

From October to March.

From April to September. 
Characteristics of cases ${ }^{\mathrm{a}}$ among travellers abroad by diagnostic category, 2010-12 $(\mathrm{n}=50,710)$

\begin{tabular}{|c|c|c|c|c|c|c|c|c|c|}
\hline Characteristic & Total & Infections & Injuries & $\begin{array}{c}\text { Skin } \\
\text { diseases }\end{array}$ & $\begin{array}{l}\text { Musculoskeletal } \\
\text { and connective } \\
\text { tissue diseases }\end{array}$ & $\begin{array}{l}\text { Diseases } \\
\text { of the } \\
\text { digestive } \\
\text { tract }^{b}\end{array}$ & $\begin{array}{l}\text { Vascular } \\
\text { diseases }^{c}\end{array}$ & Other $^{d}$ & P value ${ }^{e}$ \\
\hline $\begin{array}{l}\text { Total number, } \\
\mathrm{n}(\%)\end{array}$ & $50,710(100)$ & $30,386(59.9)$ & $7,095(14.0)$ & $2,639(5.2)$ & $2,621(5.2)$ & $1,292(2.5)$ & $1,081(2.1)$ & $5,596(11.0)$ & $<0.001$ \\
\hline $\begin{array}{l}\text { Inpatient cases, } \\
\text { n (\%) }\end{array}$ & $8,339(16.4)$ & $4,062(13.4)$ & $1,503(21.2)$ & $24(0.9)$ & $146(5.6)$ & $456(35.3)$ & $712(65.9)$ & $1,436(25.7)$ & $<0.001$ \\
\hline \multicolumn{10}{|l|}{ Case characteristics } \\
\hline Male, n (\%) & $22,849(45.1)$ & $13,451(44 \cdot 3)$ & $3,218(45.4)$ & $939(35.6)$ & $1,254(47.8)$ & $642(49.7)$ & $621(57.4)$ & $2,724(48.7)$ & $<0.001$ \\
\hline $\begin{array}{l}\text { Median age in } \\
\text { years (IQR) }\end{array}$ & $45(21-61)$ & $40(15-59)$ & $48(27-62)$ & $46(23-59)$ & $60(47-67)$ & $50(30-63)$ & $64(56-70)$ & $49(26-64)$ & $<0.001$ \\
\hline $\begin{array}{l}\text { Winter season }{ }^{f} \text {, } \\
\text { n (\%) }\end{array}$ & $30,032(59.2)$ & $18,380(60.5)$ & $3,694(52.1)$ & $1,485(56.3)$ & $1,638(62.5)$ & $768(59.4)$ & $730(67.5)$ & $3,337(59.6)$ & $<0.001$ \\
\hline \multicolumn{10}{|l|}{ Region, $\mathrm{n}(\%)^{\mathrm{g}}$} \\
\hline Southern Europe & $27,202(100)$ & $15,406(56.6)$ & $4,005(14.7)$ & $1,263(4.6)$ & $1,806(6.6)$ & $601(2.2)$ & $647(2.4)$ & $3,474(12.8)$ & $<0.001$ \\
\hline $\begin{array}{l}\text { Eastern } \\
\text { Mediterranean }\end{array}$ & $7,539(100)$ & $4,858(64.4)$ & $1,008(13.4)$ & $377(5.0)$ & $309(4.1)$ & $204(2.7)$ & $137(1.8)$ & $646(8.6)$ & $<0.001$ \\
\hline Rest of Europe & $1,958(100)$ & $840(42.9)$ & $557(28.4)$ & $47(2.4)$ & $61(3.1)$ & $87(4.4)$ & $96(4.9)$ & $270(13.8)$ & $<0.001$ \\
\hline North Africa & $3,121(100)$ & $2,516(80.6)$ & $189(6.0)$ & $202(6.5)$ & $44(1.4)$ & $56(1 \cdot 8)$ & $13(0.4)$ & $101(3.2)$ & $<0.001$ \\
\hline $\begin{array}{l}\text { Sub-Saharan } \\
\text { Africa }\end{array}$ & $141(100)$ & $70(49.6)$ & $28(19.9)$ & $1(0.7)$ & $3(2.1)$ & $5(3.5)$ & $4(2.8)$ & $30(21.3)$ & $<0.001$ \\
\hline $\begin{array}{l}\text { South-central } \\
\text { Asia }\end{array}$ & $361(100)$ & $257(71.2)$ & $45(12.5)$ & $5(1.4)$ & $5(1.4)$ & $12(3.3)$ & $12(3.3)$ & $25(6.9)$ & $<0.001$ \\
\hline South-east Asia & $9,514(100)$ & $6,081(63.9)$ & $1,113(11.7)$ & $711(7.5)$ & $354(3.7)$ & $269(2.8)$ & $141(1.5)$ & $845(8.9)$ & $<0.001$ \\
\hline North America & $243(100)$ & $60(24.7)$ & 46 (18.9) & $7(2.9)$ & $18(7.4)$ & $27(11.1)$ & $8(3.3)$ & $77(31.7)$ & $<0.001$ \\
\hline $\begin{array}{l}\text { Central and South } \\
\text { America and the } \\
\text { Caribbean }\end{array}$ & $366(100)$ & $220(60.1)$ & $53(14.5)$ & $18(4.9)$ & $9(2.5)$ & $10(2.7)$ & $9(2.5)$ & $47(12.8)$ & 0.351 \\
\hline Other ${ }^{\mathrm{h}}$ & $265(100)$ & $78(29.4)$ & $51(19.2)$ & $8(3.0)$ & $12(4.5)$ & $21(7.9)$ & $14(5.3)$ & $81(30.6)$ & $<0.001$ \\
\hline
\end{tabular}

a A case was defined as a Finnish traveller abroad with one episode of illness or injury, handled by SOS International during 2010 to 2012 . A person with several separate episodes was counted more than once.

b Other than acute gastroenteritis.

Cardiovascular, cerebrovascular, other vascular diseases.

d Neoplasms; haematological diseases; endocrine, nutritional and metabolic diseases; mental and behavioural disorders; neurological diseases; eye diseases; ear diseases; respiratory diseases; genitourinary diseases; pregnancy, childbirth and perinatology; unclassified symptoms.

e Tested using chi-squared test, except for age, for which the Kruskal-Wallis test was used.

f From October to March.

g Proportion of diagnostic category according to region (percentages in rows).

h Western Asia, north-east Asia, Australia, New Zealand, Oceania.

from the central population register, the sample totalled 26,400 individuals annually in 2010 and 2011, and 28,200 in 2012 [22].

\section{Calculation of incidence}

Proportionate morbidity figures were retrieved for all cases in the SOS database, whereas incidence calculation was restricted to adults for compatibility with the OSF population: only cases aged $15^{-} 74$ years in 2010-11 and 15-84 years in 2012 were included, and the geographical classification of OSF was applied (Nordic countries, Baltic states and Russia, eastern and western Europe; southern Europe and the eastern Mediterranean; Africa; Asia and Oceania; the Americas) [22].

Incidence figures were calculated as follows:
Total number of travel days $=$ median duration of trip $x$ estimated $\%$ of travellers with insurance $x$ number of travellers

Incidence per 100,000 travel days $=$ (number of cases $/$ total number of travel days) $\times 100,000$.

Finns have access to state-provided healthcare in countries following European Union (EU) legislation; reimbursement for costs elsewhere can also be obtained by application to the Social Insurance Institution of Finland (Kela) [24]. As compared with the number of cases handled by SOS, the proportion Kela covers is $50 \%$ higher in countries following EU legislation than elsewhere. In the Nordic and Baltic countries, the proportion exceeds 50\% (Timo Partio, Senior Statistical Analyst, Kela, personal communication, 7 October 2013) and, furthermore, Finns' visits to these countries and to Russia are 
FIGURE 2

Overall incidence ${ }^{\mathrm{a}}$ of illness and injury among adult ${ }^{\mathrm{b}}$ Finnish travellers in various regions ${ }^{c}, 2010-12$

$(9,953,000$ travellers $)$

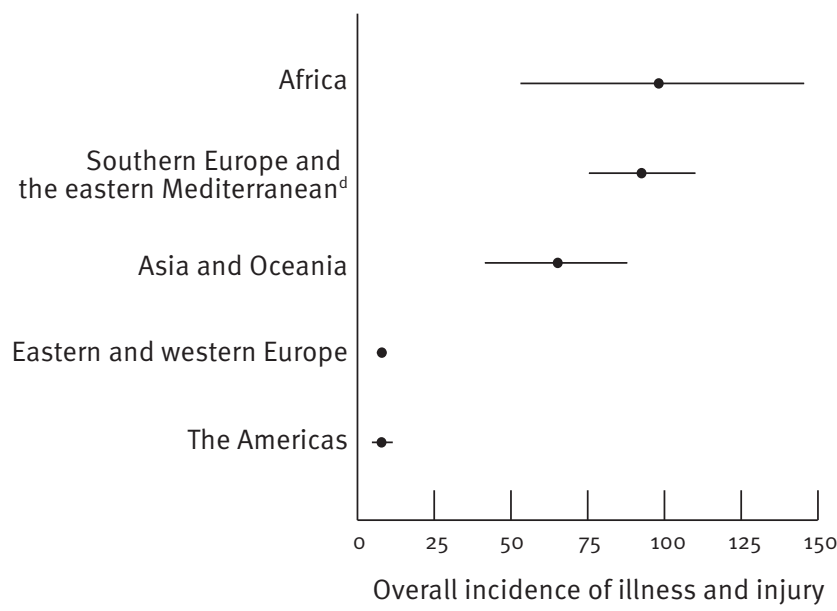

per 100,000 travel days

The bars represent $95 \%$ Bayesian credible intervals.

a Incidence per 100,000 travel days $=$ (number of cases divided by number of travel days) $\times 100,000$

b Travellers aged 15-74 years in 2010-11 and travellers aged 15-84 years in 2012 [22].

Figures for Nordic and Baltic countries and Russia are not presented here; incidences for these countries are not comparable with those of other regions because proportionally more cases are covered by the Social Insurance Institution of Finland (Kela) [24] and trips are shorter than to other regions [22].

d Balkan states, Cyprus, Greece, Italy, Israel, Malta, Portugal including Madeira, Spain including the Canary Islands, Turkey. Data source: Table 3 .

shorter than elsewhere [22]. As such differences might hamper comparison with other regions, we chose not to present incidences for the Nordic or Baltic countries or Russia.

\section{Statistical methods}

Descriptive statistics were analysed with Microsoft Excel 2010 and IBM SPSS 19.0. Differences between groups were tested with chi-squared and Student's t-tests and the Kruskal-Wallis test, as appropriate. Risk factors of hospitalisation were analysed with logistic regression. Variables with $\mathrm{p}<0.2$ in univariable analysis were included in a multivariable model. For variables lacking a reference category, deviation from the average effect was used.

We estimated $95 \%$ Bayesian credible intervals (BCls) for travel days of travellers with insurance, and thus 95\% BCls for incidences, using Bayesian modelling with Markov chain Monte Carlo (MCMC) Gibbs sampling with informative priors. The following assumptions were made: the proportion of travellers with insurance was lower (55-70\%) for eastern and western Europe and higher (75-85\%) for more distant destinations; trip durations were distributed similarly in all three years of the study (2010-12). In estimating the numbers of travellers to each destination, sampling variation in the numbers of those answering was taken into account.

\section{Results}

Study population in the SOS International database and case characteristics

The analysis included 50,710 cases; $83.6 \%$ were treated as outpatients, $16.4 \%$ as inpatients. The median age was 45 years (interquartile range (IQR): 21-61); 54.9\% were women (Table 1$)$. Most cases ( $n=36,699 ; 72.4 \%$ ) were reported to SOS in Europe plus the eastern Mediterranean. Spain had the highest number, 18,583 (36.6\%), of whom $13,435(72.3 \%)$ were in the Canary Islands.

Between regions, characteristics of cases differed significantly. Median ages ranged from 31 years (IQR: 22-45) for cases in north-east and western Asia, Australia, New Zealand and Oceania to 52 years (IQR: $23-65)$ in southern Europe ( $p<0.001)$. The proportion of men ranged from $38.1 \%$ of cases in Australia, New Zealand, and Oceania to $54.5 \%$ of those in south-east Asia ( $p<0.001)$. Most cases were reported during winter in all regions except in Europe plus the eastern Mediterranean $(p<0.001)$ (data not shown).

\section{Diagnoses and repatriations}

Infections (59.9\%) and injuries (14.0\%) constituted the largest diagnostic categories for outpatients and inpatients alike (Table 1, Table 2). The risk of hospitalisation proved greatest among cases with vascular diseases. Multivariable analyses showed other risk factors of hospitalisation to be male sex, aged $15^{-29}$ or $\geq 60$ years, and travel to sub-Saharan Africa, Australia, New Zealand and Oceania, or to Asia (other than south-east Asia) (Table 1). Significant interactions were found between all these variables.

Acute gastroenteritis (11,543 cases) proved both the most common diagnosis (22.8\% of all) and infection (38.0\%). Respiratory tract infections $(n=10,475)$ were nearly as common (20.7\% of all, $34.5 \%$ of infections). Injuries comprised 5,567 (78.5\%) traumas and 1,528 $(21.5 \%)$ others. Of the traumas, 4,270 (76.7\%) were superficial, 952 (17.1\%) fractures and 287 (5.2\%) intracranial injuries.

Return travel itineraries remained unchanged for 48,842 cases (96.3\%), an air ambulance was used for $113(0.2 \%)$, and 1,556 (3.1\%) had some other changed transport arrangement. Deaths totalled 199 (0.4\%).

\section{Incidence of illness or injury}

Overall incidence of illness and injury was greatest in Africa and southern Europe plus the eastern Mediterranean, as well as Asia plus Oceania; incidences were lowest in the Americas and eastern plus western Europe (Table 3, Figure 2). Looking at individual countries' data available for comparison, incidence 

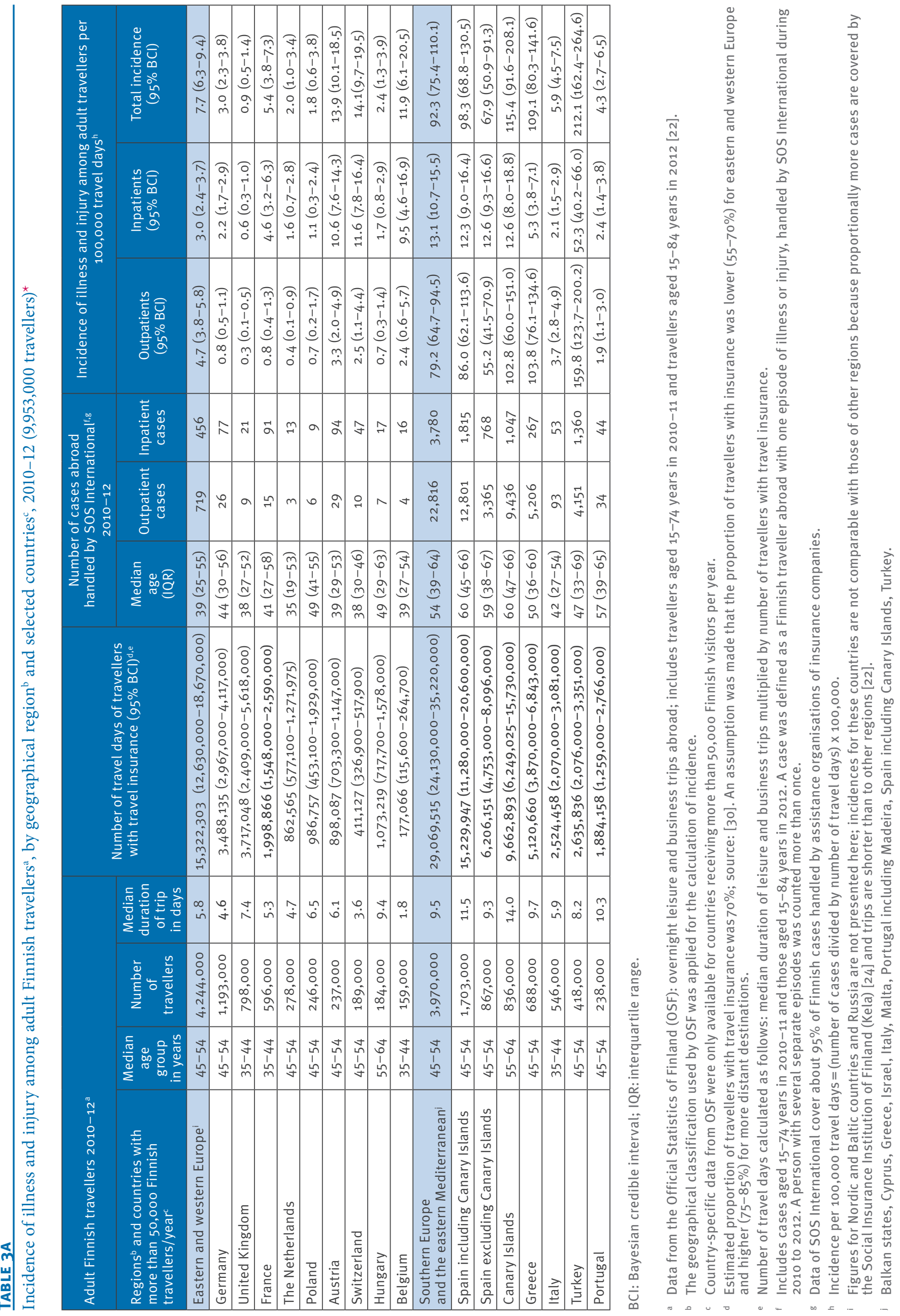

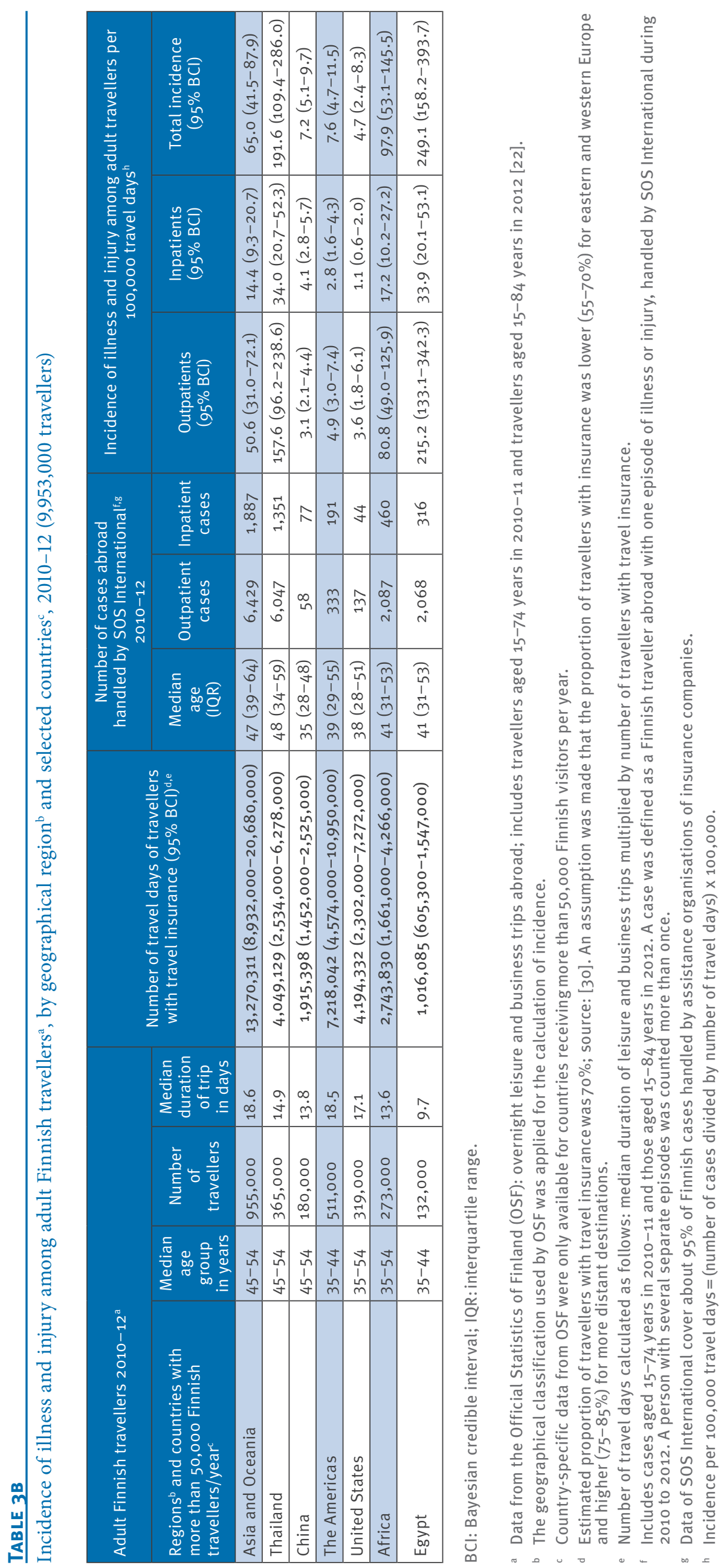


\section{TABLE 4}

Incidence of injuries and infections among adult Finnish travellers ${ }^{\mathrm{a}}$ in various geographical regions ${ }^{\mathrm{b}}$ and selected countries ${ }^{\mathrm{c}}$, 2010-12 (9,953,000 travellers)

\begin{tabular}{|c|c|c|c|c|c|c|c|c|}
\hline \multirow{4}{*}{$\begin{array}{l}\text { Regions and } \\
\text { countries visited }{ }^{\mathrm{b}, \mathrm{c}} \\
\text { Regions and } \\
\text { countries with more } \\
\text { than 50,000 Finnish } \\
\text { travellers/year }\end{array}$} & \multicolumn{8}{|c|}{$\begin{array}{l}\text { Number of } \text { cases }^{\mathrm{d}, \mathrm{e}} \\
\text { and incidence (per 100,000 travel days) }{ }^{f} \text { of injuries and infections among adult travellers }\end{array}$} \\
\hline & \multicolumn{4}{|c|}{ Largest diagnostic main categories } & \multicolumn{4}{|c|}{ Largest infection subcategories } \\
\hline & \multicolumn{2}{|c|}{ Injuries total } & \multicolumn{2}{|c|}{ Infections total } & \multicolumn{2}{|c|}{ Acute gastroenteritis } & \multicolumn{2}{|c|}{ Acute respiratory infections } \\
\hline & Number & $\begin{array}{l}\text { Incidence } \\
(95 \% \mathrm{BCl})\end{array}$ & Number & $\begin{array}{l}\text { Incidence } \\
(95 \% \mathrm{BCl})\end{array}$ & Number & $\begin{array}{l}\text { Incidence } \\
(95 \% \mathrm{BCl})\end{array}$ & Number & $\begin{array}{l}\text { Incidence } \\
(95 \% \mathrm{BCl})\end{array}$ \\
\hline $\begin{array}{l}\text { Eastern and western } \\
\text { Europe }^{\mathrm{g}}\end{array}$ & 401 & $\begin{array}{c}2.6 \\
(2.1-3.2)\end{array}$ & 461 & $\begin{array}{c}3.0 \\
(2.4-3.7)\end{array}$ & 191 & $\begin{array}{c}1.3 \\
(1.0-1.6)\end{array}$ & 140 & $\begin{array}{c}0.9 \\
(0.7-1.2)\end{array}$ \\
\hline Germany & 26 & $\begin{array}{c}0.8 \\
(0.5-1.1)\end{array}$ & 20 & $\begin{array}{c}0.6 \\
(0.3-0.9)\end{array}$ & 7 & $\begin{array}{c}0.2 \\
(0.1-0.4)\end{array}$ & 6 & $\begin{array}{c}0.2 \\
(0.1-0.3)\end{array}$ \\
\hline United Kingdom & 13 & $\begin{array}{c}0.4 \\
(0.2-0.7)\end{array}$ & 7 & $\begin{array}{c}0.2 \\
(0.1-0.4)\end{array}$ & 0 & $\begin{array}{c}0.0 \\
(0-0)\end{array}$ & 5 & $\begin{array}{c}0.1 \\
(0-0.3)\end{array}$ \\
\hline France & 50 & $\begin{array}{c}2.6 \\
(1.7-3.6) \\
\end{array}$ & 16 & $\begin{array}{c}0.8 \\
(0.4-1.3)\end{array}$ & 9 & $\begin{array}{c}0.5 \\
(0.2-0.8)\end{array}$ & 2 & $\begin{array}{c}0.1 \\
(0-0.3)\end{array}$ \\
\hline The Netherlands & 10 & $\begin{array}{c}1.2 \\
\left(0.5^{-2.3}\right)\end{array}$ & 1 & $\begin{array}{c}0.1 \\
(0-0.5)\end{array}$ & 1 & $\begin{array}{c}0.1 \\
(0-0.5)\end{array}$ & 0 & $\begin{array}{c}0.0 \\
(0-0)\end{array}$ \\
\hline Poland & 4 & $\begin{array}{c}0.5 \\
(0.1-1.3) \\
\end{array}$ & 4 & $\begin{array}{c}0.5 \\
(0.1-1.2) \\
\end{array}$ & 0 & $\begin{array}{c}0.0 \\
(0-0)\end{array}$ & 2 & $\begin{array}{c}0.2 \\
(0-0.8)\end{array}$ \\
\hline Austria & 103 & $\begin{array}{c}11.7 \\
(8.3-15.7) \\
\end{array}$ & 8 & $\begin{array}{c}0.9 \\
(0.4-1.7)\end{array}$ & 5 & $\begin{array}{c}0.6 \\
(0.2-1.2) \\
\end{array}$ & 2 & $\begin{array}{c}0.2 \\
(0-0.7)\end{array}$ \\
\hline Switzerland & 39 & $\begin{array}{c}9.6 \\
(6.3-13.9) \\
\end{array}$ & 8 & $\begin{array}{c}2.0 \\
(0.8-3 \cdot 7) \\
\end{array}$ & 1 & $\begin{array}{c}0.3 \\
(0-1.0)\end{array}$ & 3 & $\begin{array}{c}0.8 \\
(0.2-1.8) \\
\end{array}$ \\
\hline Hungary & 6 & $\begin{array}{c}0.6 \\
(0.2-1.3)\end{array}$ & 6 & $\begin{array}{c}0.6 \\
(0.2-1.3)\end{array}$ & 2 & $\begin{array}{c}0.2 \\
(0-0.6)\end{array}$ & 2 & $\begin{array}{c}0.2 \\
(0-0.6)\end{array}$ \\
\hline Belgium & 7 & $\begin{array}{c}4.2 \\
(1.5-8.6)\end{array}$ & 3 & $\begin{array}{c}1.8 \\
(0.4-4 \cdot 7)\end{array}$ & 1 & $\begin{array}{c}0.6 \\
(0-2.4)\end{array}$ & 1 & $\begin{array}{c}0.6 \\
(0-2.4)\end{array}$ \\
\hline $\begin{array}{l}\text { Southern Europe and } \\
\text { the eastern } \\
\text { Mediterranean }^{\text {h }}\end{array}$ & 4,034 & $\begin{array}{c}14 \cdot 0 \\
\left(11.4^{-16.7}\right)\end{array}$ & 14,607 & $\begin{array}{c}50.6 \\
(40.7-60.4) \\
\end{array}$ & 4,655 & $\begin{array}{c}16.2 \\
\left(13.4^{-19.2)}\right.\end{array}$ & 6,199 & $\begin{array}{c}21.4 \\
(17.4-25.4)\end{array}$ \\
\hline $\begin{array}{l}\text { Spain including } \\
\text { Canary Islands }\end{array}$ & 1,863 & $\begin{array}{c}12.7 \\
(9.2-17.0)\end{array}$ & 8,128 & $\begin{array}{c}55.0 \\
(39.7-74.7)\end{array}$ & 2,201 & $\begin{array}{c}15.1 \\
(10.9-20.1)\end{array}$ & 4,140 & $\begin{array}{c}27.6 \\
(20.1-35.5) \\
\end{array}$ \\
\hline $\begin{array}{l}\text { Spain excluding } \\
\text { Canary Islands }\end{array}$ & 631 & $\begin{array}{c}10.3 \\
(7.6-13.5) \\
\end{array}$ & 1,945 & $\begin{array}{c}31.7 \\
(23.2-42.0) \\
\end{array}$ & 439 & $\begin{array}{c}7.2 \\
(5.3-9.6) \\
\end{array}$ & 976 & $\begin{array}{c}16.1 \\
(11.8-21.3) \\
\end{array}$ \\
\hline Canary Islands & 1,232 & $\begin{array}{c}14.6 \\
(8.9-22.9)\end{array}$ & 6,183 & $\begin{array}{c}72.3 \\
(47.8-107.6)\end{array}$ & 1,762 & $\begin{array}{c}21.4 \\
(13.2-32.8)\end{array}$ & 3,164 & $\begin{array}{c}36.7 \\
(23.1-56.6)\end{array}$ \\
\hline Greece & 1,137 & $\begin{array}{c}22.5 \\
(16.2-29.8) \\
\end{array}$ & 2,682 & $\begin{array}{c}52.8 \\
(37.7-70.6)\end{array}$ & 598 & $\begin{array}{c}11.9 \\
(8.6-15.7)\end{array}$ & 1,107 & $\begin{array}{c}21.9 \\
(15.9-29.0) \\
\end{array}$ \\
\hline Italy & 53 & $\begin{array}{c}2.1 \\
(1.5-2.9) \\
\end{array}$ & 53 & $\begin{array}{c}2.1 \\
(1.5-2.9) \\
\end{array}$ & 7 & $\begin{array}{c}0.3 \\
(0.1-0.5) \\
\end{array}$ & 26 & $\begin{array}{c}1.0 \\
(0.6-1.6) \\
\end{array}$ \\
\hline Turkey & 775 & $\begin{array}{c}29.7 \\
(22.7-37.7) \\
\end{array}$ & 3,353 & $\begin{array}{c}127.4 \\
(97.9-161.4) \\
\end{array}$ & 1,766 & $\begin{array}{c}67.9 \\
(52.5-85.3) \\
\end{array}$ & 786 & $\begin{array}{c}30.2 \\
(22.9-38.3)\end{array}$ \\
\hline Portugal & 26 & $\begin{array}{c}1.4 \\
(0.8-2.4)\end{array}$ & 16 & $\begin{array}{c}0.9 \\
(0.4-1.6)\end{array}$ & 6 & $\begin{array}{c}0.3 \\
(0.1-0.7)\end{array}$ & 7 & $\begin{array}{c}0.4 \\
(0.1-0.8)\end{array}$ \\
\hline Asia and Oceania & 1,089 & $\begin{array}{c}8.2 \\
\left(5.4^{-11.8)}\right.\end{array}$ & 5,042 & $\begin{array}{c}37.4 \\
(23.8-53.5)\end{array}$ & 2,663 & $\begin{array}{c}20.6 \\
(14.2-29.5) \\
\end{array}$ & 1,170 & $\begin{array}{c}8.9 \\
(5.9-13.0)\end{array}$ \\
\hline Thailand & 946 & $\begin{array}{c}23.7 \\
(14.6-36.4)\end{array}$ & 4,538 & $\begin{array}{c}112.0 \\
(66.0-165.3)\end{array}$ & 2,341 & $\begin{array}{c}59.0 \\
(37.5-90.8) \\
\end{array}$ & 1,088 & $\begin{array}{c}27.8 \\
(17.5-41.4)\end{array}$ \\
\hline China & 27 & $\begin{array}{c}1.4 \\
(0.9-2.2)\end{array}$ & 37 & $\begin{array}{c}2.0 \\
(1.2-2.9)\end{array}$ & 14 & $\begin{array}{c}0.8 \\
(0.4-1.3)\end{array}$ & 13 & $\begin{array}{c}0.7 \\
(0.3-1.2)\end{array}$ \\
\hline The Americas & 89 & $\begin{array}{c}1.3 \\
(0.8-2.0) \\
\end{array}$ & 244 & $\begin{array}{c}3 \cdot 5 \\
(2.1-5 \cdot 3) \\
\end{array}$ & 120 & $\begin{array}{c}1.8 \\
(1.1-2.7) \\
\end{array}$ & 67 & $\begin{array}{c}1.0 \\
(0.6-1.5)\end{array}$ \\
\hline United States & 34 & $\begin{array}{c}0.9 \\
(0.4-1.6) \\
\end{array}$ & 45 & $\begin{array}{c}1.2 \\
(0.6-2.1) \\
\end{array}$ & 7 & $\begin{array}{c}0.2 \\
(0.1-0.4) \\
\end{array}$ & 17 & $\begin{array}{c}0.4 \\
(0.2-0.9) \\
\end{array}$ \\
\hline Africa & 181 & $\begin{array}{c}6.7 \\
(3.8-10.5)\end{array}$ & 1,977 & $\begin{array}{c}77.0 \\
(48.3-119.5) \\
\end{array}$ & 1,684 & $\begin{array}{c}63.0 \\
(38.0-100.3)\end{array}$ & 179 & $\begin{array}{c}6.6 \\
(3.9-10.5) \\
\end{array}$ \\
\hline Egypt & 144 & $\begin{array}{c}15.6 \\
(9.0-25.2)\end{array}$ & 1,904 & $\begin{array}{c}197.9 \\
(114.7-308.1)\end{array}$ & 1,631 & $\begin{array}{c}184.6 \\
(110.6-290.5)\end{array}$ & 173 & $\begin{array}{c}18.6 \\
(10.7-29.8)\end{array}$ \\
\hline
\end{tabular}

$\mathrm{BCl}=$ Bayesian credible interval.

Data from the Official Statistics of Finland (OSF): overnight leisure and business trips abroad; includes travellers aged $15-74$ years in 2010-11 and travellers aged 15-84 years in 2012 [22].

The geographical classification used by OSF was used for the calculation of incidence.

Country-specific data from OSF were only available for countries receiving more than 50,000 Finnish visitors per year.

Includes cases aged 15-74 years in 2010-11 and 15-84 years in 2012, who sought medical care abroad during 2010 to 2012 , handled by SOS International. A case was defined as a Finnish traveller abroad with one episode of illness or injury, handled by SOS International during 2010 to 2012. A person with several separate episodes was counted more than once.

The data of SOS International cover about $95 \%$ of Finnish cases handled by assistance organisations of insurance companies.

Incidence per 100,000 travel days = (number of cases divided by number of travel days) $\times 100,000$.

Figures for Nordic and Baltic countries and Russia are not presented here; incidences for these countries are not comparable with those of other regions because proportionally more cases are covered by the Social Insurance Institution of Finland (Kela) [24] and trips are shorter than to other regions [22].

Balkan states, Cyprus, Greece, Israel, Italy, Malta, Portugal including Madeira, Spain including Canary Islands, Turkey. 


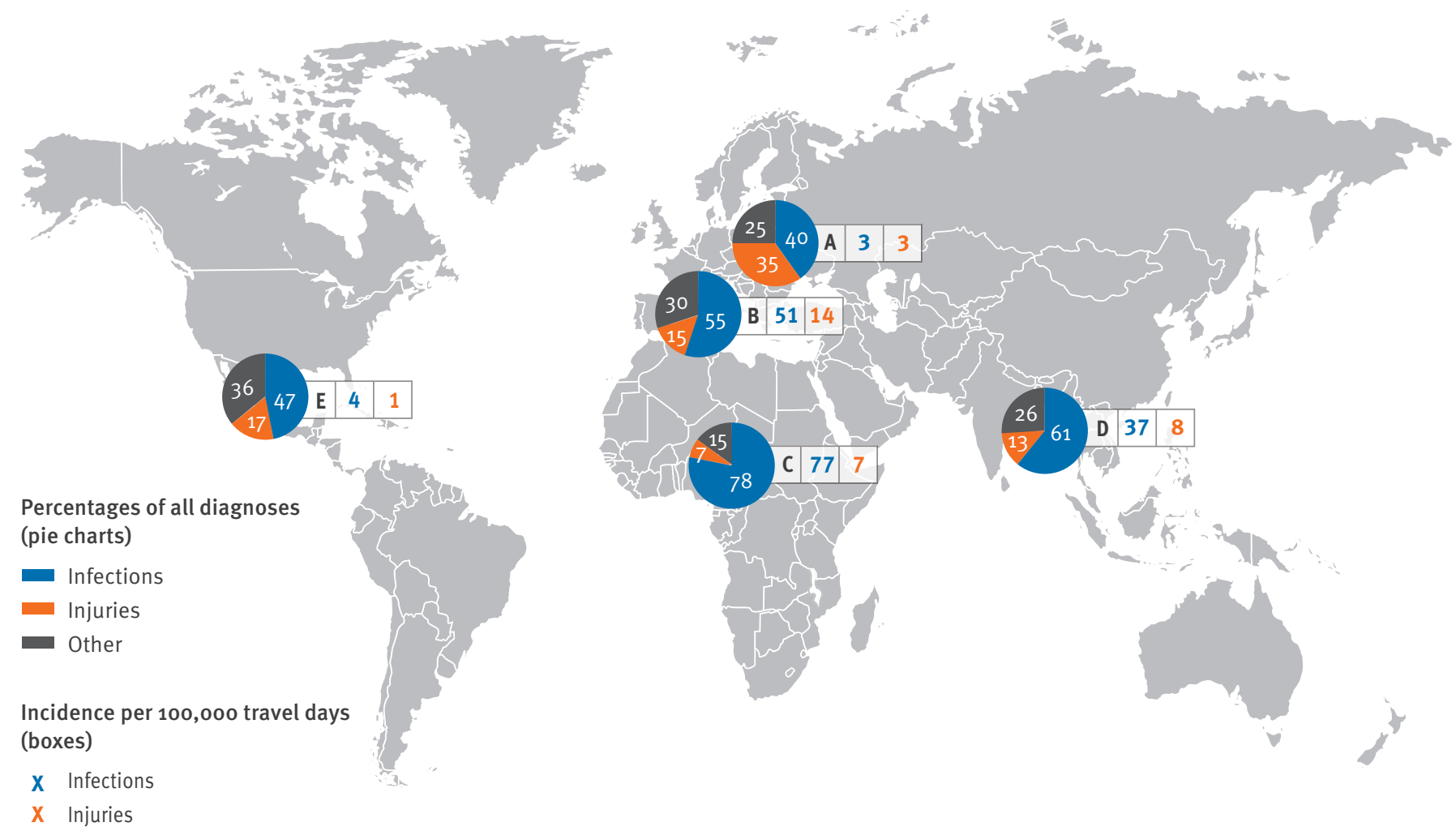

A: eastern and western Europe; B: southern Europe and the eastern Mediterranean; C: Africa; D: Asia and Oceania; E: the Americas.

'Other' refers to diagnoses other than infections or injuries (skin diseases; musculoskeletal and connective tissue diseases; diseases of the digestive tract; vascular diseases; neoplasms; haematological diseases; endocrine, nutritional and metabolic diseases; mental and behavioural disorders; neurological diseases; eye diseases; ear diseases; respiratory diseases; genitourinary diseases; pregnancy, childbirth and perinatology; unclassified symptoms).

a Includes cases aged 15-74 years in 2010-11, and those aged 15-84 years in 2012. A case was defined as a Finnish traveller abroad with one episode of illness or injury, handled by SOS International during 2010 to 2012 . A person with several separate episodes was counted more than once.

b Figures for Nordic and Baltic countries and Russia are not presented here; incidences for these countries are not comparable with those of other regions because proportionally more cases are covered by the Social Insurance Institution of Finland (Kela) [24] and trips are shorter than to other regions [22].

Data source: Table 4 .

proved highest in Egypt, Turkey, and Thailand, and varied between countries within southern Europe.

Infection incidence was greatest in Africa, followed by southern Europe plus the eastern Mediterranean, and Asia plus Oceania. As for injuries, incidence proved highest in southern Europe plus the eastern Mediterranean (Table 4, Figure 3).

\section{Discussion}

\section{Principal findings}

For decades, travel medicine research has striven to outline the risks of health problems at various destinations. As data have been unrelated to numbers of travellers per site, the main point of criticism has been that proportions of health problems easily suffer distortion [20]. Some reports have described single imported diseases in relation to national travel statistics [25] or
World Tourism Organization data [26,27], but a thorough overview of travellers' health risks has been lacking.

Our investigation draws on the exceptional situation in Finland, with two large databases available: one maintained by a single travellers' assistance organisation, covering about $95 \%$ of Finnish cases, and the other by OSF, providing numerical data on Finnish travellers to various destinations. Combining these enabled not only a virtually comprehensive nationwide analysis of proportionate morbidity for various diagnoses, but also incidence calculation of health problems abroad. These data reveal the great incidence of infections and the significant difference in incidence of illness and injury between the various regions. 
Strengths and weaknesses

The major novelty of our work lies in presenting incidences of illnesses and injuries in various geographical regions. Even though the proportionate morbidity data presented in this and previous [2-19] studies are very informative, the incidence figures are of special value, as they describe more accurately the risks for travellers and, as illustrated in Figure 3, allow comparisons between various regions. Our study sample represents the most severe cases, yet the actual incidence of health problems among travellers needing medical care abroad may in reality be sixfold higher than that presented here (Figure 1). While this study is, to the best of our knowledge, the largest to date reporting health problems of travellers while abroad, the data do not cover travellers who did not contact insurance companies/assistance organisations, nor those without insurance, or those making a claim afterwards directly to the insurance company. According to Finland's largest travel insurance company, the last group mentioned comprise mostly uncomplicated outpatient cases, while nearly all inpatients abroad are cared for by assistance organisations (Ilkka Valanne, Claims Specialist, Eurooppalainen, personal communication, 2 October 2013). As our study material covers $95 \%$ of all Finnish cases handled by assistance organisations, the data represent quite comprehensively the most serious health problems faced by Finnish travellers.

The SOS database lacked information on duration of and reason for travel, and itinerary of individual cases, and no evaluations could be made in relation to these factors. Studies relying on questionnaires and telephone interviews [2,7-14] represent travellers' own reports, not evaluations made by healthcare professionals; those based on travel insurance claims $[15,16]$ are a mixture of both. One of the strengths of our study is data collection directly from clinicians treating the patient abroad.

\section{Results in relation to findings in other studies}

\section{Findings on proportionate morbidity}

In our study, infections clearly outnumbered all other health problems during travel. The proportion of infections proved higher than in studies from Switzerland, Australia and Norway, also using data of assistance organisations $(60 \%$ vs $20-40 \%)$ [17-19], possibly because, instead of organ-specific categories, we grouped all infections together, in a category of their own.

The most common single diagnosis was acute gastroenteritis (23\%), consistent with previous findings on illness abroad [2,8-14,28], accounting for one third of inpatient cases. Respiratory infections proved nearly as common (21\%), yet with less frequent hospitalisation than for gastroenteritis. In prospective studies, respiratory infections have been reported in $2-26 \%$ of travellers [2,7-14].
Findings on incidence of illness and injury

The overall incidence proved highest in Africa, southern Europe plus the eastern Mediterranean, and Asia plus Oceania. One remarkable finding was that in southern Europe plus the eastern Mediterranean, figures for injuries and infections proved higher than those for eastern plus western Europe. The infection profile differed from that in Africa and Asia: instead of acute gastroenteritis, incidence in southern Europe plus the eastern Mediterranean was highest for respiratory tract infections, except for Turkey, which showed the opposite.

Comparisons of incidence figures were possible between countries with more than 50,000 annual visitors. Some caution should, however, be used when making comparisons, since differences between healthcare services may influence the figures in Europe: in countries with large numbers of tourists, such as Spain, there are private clinics directly contacting assistance organisations, whereas for countries with fewer private hospitals, the proportion of cases reported to SOS may remain smaller.

In eastern plus western Europe, where data could be compared between several countries, there was on the whole a minor incidence of health problems. The incidence of injuries was high in Austria and Switzerland, probably mostly accounted for by skiing accidents (Mikael Fotopoulos, SOS International, personal communication, 14 July 2014). In southern Europe plus the eastern Mediterranean, comparisons could be made between Greece, Italy, Portugal, Spain, and Turkey. In Italy and Portugal, overall incidence of illness and injury proved similar to that in eastern plus western Europe. The high overall incidence in Turkey was attributed to gastroenteritis, whereas the next highest figures in Greece and Spain were mainly due to respiratory tract infections. Greenwood et al. described a low risk of gastroenteritis for southern Europe [27], yet we found an elevated incidence in Greece and Spain.

The incidence figures reflect not only health hazards, but also the characteristics of travellers: in the multivariable analysis, vascular diseases, male sex and age $\geq 60$ years, for example, were risk factors for hospitalisation.

Likelihood of illness increases with duration of travel $[2,29]$. In the OSF data, the farther the destination, the longer was the stay (Table 3). For travellers to southern Europe plus the eastern Mediterranean, the median duration was longest for the Canary Islands; intermediate for mainland Spain, Greece and Portugal; and shortest for Turkey and Italy. The overall incidence of illness and injury proved, however, highest in Turkey and the Canary Islands, followed by Greece and mainland Spain. Thus, length of stay alone does not account for these differences. Within this same region, travellers to the Canary Islands were older, and to Italy younger than those to other destinations, consistent with the 
age distribution of our cases. Travellers' age and travel duration may thus partly explain the high incidence in the Canary Islands and the low in Italy. Nevertheless, it appears that the overall incidence in southern Europe plus the eastern Mediterranean exceeded that elsewhere in Europe.

\section{Conclusions}

This study shows a clear predominance of infections among Finnish travellers' health problems. This investigation is the first to present such comprehensive data on incidence of illnesses and injuries during travel. It thus provides tools for risk assessment, destinationspecific travel counselling and post-travel evaluation. As the types of exposure in a given destination are alike for all travellers, regardless of the country of origin, the results of this study should be applicable to any country with a similar travel pattern.

A noteworthy conclusion is that travel within Europe is not without risk. Pre-travel advice may also be needed also for visitors to southern Europe.

\section{*Erratum}

In Table 3, the number of travellers in eastern and western Europe were incorrect. Also the median age group for Spain excluding the Canary Islands was incorrect. These errors were corrected on 25 May 2015, at the request of the authors.

\section{Acknowledgments}

The study was supported by the Maud Kuistila Memorial Foundation and the Finnish Governmental Subsidy for Health Science Research. The study sponsors had no role in study design and the collection, analysis, and interpretation of data and the writing of the article and the decision to submit it for publication.

We thank Ilkka Valanne (Claims Specialist, Eurooppalainen), Ari Kinnunen (Medical Director, EMA Finland), Pauli Haapsaari (Medical Director, MedFlight Finland), Timo Partio (Senior Statistical Analyst, the Social Insurance Institution of Finland), and Taru Tamminen (Statistician, the Official Statistics of Finland) for providing information invaluable for the interpretation of the results. We thank Carol Norris for editing the final manuscript.

\section{Conflict of interest}

None declared.

\section{Authors' contributions}

Study concept and design: HS, AK; acquisition of data HS, MF; analysis and interpretation of data HS, PK, AK; statistical analysis HS, PK, JO; drafting of the manuscript HS, AK; critical comments on the manuscript PK, MF, JO; final approval of the version published HS, PK, MF, JO, AK.

\section{References}

1. World Tourism Organization (UNWTO). UNWTO tourism highlights, 2013 edition. Madrid: UNWTO; 2013. [Accessed 26
Feb 2014]. 2014 version available from: http://mkt.unwto.org/ en/publication/unwto-tourism-highlights-2013-edition

2. Hill DR. Health problems in a large cohort of Americans traveling to developing countries. J Travel Med. 2000;7(5):259-66. Available from: http://dx.doi. org/10.2310/7060.2000.00075 PMID:11231210

3. Freedman DO, Weld LH, Kozarsky PE, Fisk T, Robins R, von Sonnenburg F, et al. Spectrum of disease and relation to place of exposure among ill returned travelers. N Engl J Med. 2006;354(2):119-30. Available from: http://dx.doi.org/10.1056/ NEJMoa051331 PMID:16407507

4. Gautret $P$, Schlagenhauf $P$, Gaudart J, Castelli F, Brouqui $P$, von Sonnenburg F, et al. Multicenter EuroTravNet/GeoSentinel study of travel-related infectious diseases in Europe. Emerg Infect Dis. 2009;15(11):1783-90. Available from: http://dx.doi. org/10.3201/eid1511.091147 PMID:19891866

5. Field V, Gautret P, Schlagenhauf P, Burchard GD, Caumes $E$, Jensenius $M$, et al. Travel and migration associated infectious diseases morbidity in Europe, 2008. BMC Infect Dis. 2010;10:330. 10.1186/1471-2334-10-330

6. Leder K, Torresi J, Libman MD, Cramer JP, Castelli F, Schlagenhauf $P$, et al. GeoSentinel surveillance of illness in returned travelers, 2007-2011. Ann Intern Med. 2013;158(6):456-68. Available from: http://dx.doi. org/10.7326/0003-4819-158-6-201303190-00005 PMID:23552375

7. Steffen R, Rickenbach M, Wilhelm U, Helminger A, Schär M. Health problems after travel to developing countries. I Infect Dis. 1987;156(1):84-91. Available from: http://dx.doi. org/10.1093/infdis/156.1.84 PMID:3598228

8. Getz L, Larssen KE, Dahl B, Westin S. Health problems in Norwegians travelling to distant countries. Scand J Prim Health Care. 1990;8(2):95-100. Available from: http://dx.doi. org/10.3109/02813439008994938 PMID:2218161

9. Ahlm C, Lundberg S, Fessé K, Wiström J. Health problems and self-medication among Swedish travellers. Scand J Infect Dis. 1994;26(6):711-7. Available from: http://dx.doi. org/10.3109/00365549409008640 PMID:7747095

10. Bruni M, Steffen R. Impact of Travel-Related Health Impairments. J Travel Med. 1997;4(2):61-4. Available from: http://dx.doi.org/10.1111/j.1708-8305.1997.tbo0781.x PMID:9815483

11. Scoville SL, Bryan JP, Tribble D, Paparello SF, Malone JL, Ohl CA, et al. Epidemiology, preventive services, and illnesses of international travelers. Mil Med. 1997;162(3):172-8. PMID:9121662

12. Evans MR, Shickle D, Morgan MZ. Travel illness in British package holiday tourists: prospective cohort study. J Infect. 2001;43(2):140-7. Available from: http://dx.doi.org/10.1053/ jinf.2001.0876 PMID:11676522

13. Rack J, Wichmann O, Kamara B, Günther M, Cramer J, Schönfeld $C$, et al. Risk and spectrum of diseases in travelers to popular tourist destinations. J Travel Med. 2005;12(5):248-53. Available from: http://dx.doi.org/10.2310/7060.2005.12502 PMID:16256047

14. Fleck S, Jäger $H$, Zeeb $H$. Travel and health status: a survey follow-up study. Eur J Public Health. 2006;16(1):96-100. Available from: http://dx.doi.org/10.1093/eurpub/cki144 PMID:16030132

15. Liese B, Mundt KA, Dell LD, Nagy L, Demure B. Medical insurance claims associated with international business travel. Occup Environ Med. 1997;54(7):499-503. Available from: http://dx.doi.org/10.1136/oem.54.7.499 PMID:9282127

16. Tomaszunas S. Diseases, accidents and injuries among travelers in Poland. Int Marit Health. 2000;51(1-4):62-72. PMID:11214112

17. Somer Kniestedt RA, Steffen R. Travel health insurance: indicator of serious travel health risks. I Travel Med. 2003;10(3):185-8. Available from: http://dx.doi. org/10.2310/7060.2003.35770 PMID:12757694

18. Leggat PA, Griffiths R, Leggat FW. Emergency assistance provided abroad to insured travellers from Australia. Travel Med Infect Dis. 2005;3(1):9-17. Available from: http://dx.doi. org/10.1016/j.tmaid.2004.07.002 PMID:17291999

19. Lerdal A, Harding T, Kjølstad S. Illness and injury presenting to a Norwegian travel insurance company's helpline. Travel Med Infect Dis. 2007;5(3):165-70. Available from: http://dx.doi. org/10.1016/j.tmaid.2006.09.006 PMID:17448943

20. Leder K, Wilson ME, Freedman DO, Torresi J. A comparative analysis of methodological approaches used for estimating risk in travel medicine. J Travel Med. 2008;15(4):263-72. Available from: http://dx.doi.org/10.1111/j.1708-8305.2008.00218.x PMID:18666927 
21. Official Statistics of Finland (OSF). Preliminary population statistics. Helsinki: Statistics Finland. [Accessed 9 May 2015]. Available from: http://www.stat.fi/til/vamuu/index_en.html

22. Official Statistics of Finland (OSF). Finnish travel. Helsinki: Statistics Finland. [Accessed 26 Feb 2014]. Available from: http://www.stat.fi/til/smat/index_en.html

23. World Health Organization (WHO). International Statistical Classification of Diseases and Related Health Problems 10th Revision. Geneva: WHO. [Accessed 26 Feb 2014]. ICD-10 version: 2015 available from: http://apps.who.int/ classifications/icd10/browse/2015/en

24. Social Insurance Institution of Finland (Kela). Sairaanhoito kansainvälisissä tilanteissa. [Health care in international circumstances]. Helsinki: Kela. [Accessed 26 Feb 2014]. Finnish. Available from: http://www.kela.fi/ sairaanhoito-ulkomailla

25. Askling HH, Nilsson J, Tegnell A, Janzon R, Ekdahl K. Malaria risk in travelers. Emerg Infect Dis. 2005;11(3):436-41. Available from: http://dx.doi.org/10.3201/eid1103.040677 PMID:15757560

26. Leder K, Black J, O’Brien D, Greenwood Z, Kain KC, Schwartz $\mathrm{E}$, et al. Malaria in travelers: a review of the GeoSentinel surveillance network. Clin Infect Dis. 2004;39(8):110412. Available from: http://dx.doi.org/10.1086/424510 PMID:15486832

27. Greenwood Z, Black J, Weld L, O’Brien D, Leder K, Von Sonnenburg F, et al. Gastrointestinal infection among international travelers globally. J Travel Med. 2008;15(4):2218. Available from: http://dx.doi.org/10.1111/j.1708 8305.2008.00203.x PMID:18666921

28. Steffen R, deBernardis C, Baños A. Travel epidemiology--a global perspective. Int J Antimicrob Agents. 2003;21(2):8995. Available from: http://dx.doi.org/10.1016/So9248579(02)00293-5 PMID:12615369

29. Leder K, Sundararajan V, Weld L, Pandey P, Brown G, Torresi J. Respiratory tract infections in travelers: a review of the GeoSentinel surveillance network. Clin Infect Dis. 2003;36(4):399-406. http://dx.doi.org/10.1086/346155 PMID:12567296

30. Federation of Finnish Financial Services (FFI).

Vakuutustutkimus 2012 [Insurance survey 2012]. Helsinki: FFI. [Accessed 11 Nov 2013]. Finnish. Available from: http://www.fkl.fi/materiaalipankki/julkaisut/Julkaisut/ Vakuutustutkimus_2012.pdf 